\title{
Critical Thinking in University through a Curriculum-wide Reading and Writing Project
}

\author{
James Dunn \\ Aichi University \\ (D)/0000-0002-5469-180X \\ DOI: https://dx.doi.org/10.46679/978819484836308
}

\section{Abstract}

Critical thinking has gained popularity in the English as a foreign language (EFL) educational arena of late in Japan due to the Ministry of Education (MEXT) updating its requirements of English education to include logical thinking. This has caused the need for educators in Japan to quickly adapt to the inclusion of logical thinking, and by extension, critical thinking in their curriculum (MEXT, 2011) from 2013. Even though MEXT has required critical thinking to be included in the classroom, it seems very little has been done to include true critical thinking into textbooks and institutions' curriculum designs. One crucial component of the language teaching curriculum is the ability to think rationally, objectively, and deeply about a topic, or in other words, to think critically. Critical thinking has been shown to foster students' abilities to analyze, evaluate, and judge the value of the information presented to them both inside, and outside, the classroom (Lund, 2016). Critical thinking also helps students to make their own decisions related to their academic, and future employment, success (Nold, 2017). In a university-level reading and writing course in Japan, for example, students must create manuscripts at beginner to advanced levels that somewhat adhere to the expectations of academic English communities (Fang \& Schleppegrell, 2010) when it comes to topic development and utilizing source information. In order to reflect on, and thereby judge the veracity of, the information presented to 
them either by their textbook in the classroom or by external sources, critical thinking skills allow students to deconstruct, reflect upon, and assign value to information sources. This also allows them to construct their own content on two levels, one, projecting their creativity as independent thinkers, and two, linguistically as writers who can think about a topic more deeply.

The purpose of this paper is to share the planning, design, and implementation of a critical thinking reading and writing project which was introduced into the second-year EFL reading and writing focused courses at Tokai University from the spring and fall semesters of 2019. The reading and writing course, named Academic English (AE), was split into three levels depending upon the students' performance in their first-year English courses. Each level of the AE course had a project book that was individualized for their corresponding textbook and level. The project's focus, for all levels, was to develop critical thinking skills through the introduction of reflective thinking, logical fallacies, and research skills. At the end of the project, students were asked to apply their critical thinking skills to their textbook and research the veracity of the information presented to them in one of their required readings during the course. The overall reception of the project by the students was positive and results of a post-project questionnaire showed that students felt they had gained some mastery over critical thinking on subjects both in the classroom and in their lives. The project has seen success in allowing students to become learners who are more independent in their thinking, more critical in their reception to information provided to them, and better writers who are able to think on a topic more deeply and logically.

Keywords: English language learners, higher-order thinking skills, curriculum design, task-based project 


\section{This is a limited preview of the chapter.}

To read the full-text chapter, get access by purchasing this chapter or consider buying the complete book. If your library has subscription to EBSCOhost, the chapter including other chapters of the book can be accessed through your library.

This chapter is a part of the book, 'Development of Innovative Pedagogical Practices for a Modern Learning Experience' ISBN (paperback): 978-81948483-6-3; ISBN (ebook): 978-81-948483-7-0

Book DOI: https://dx.doi.org/10.46679/9788194848363

Available via CSMFL Bookstore, Amazon, Google Play Books, EBSCOhost \& EBSCO eBooks 
had more difficulty than the higher levels. While this was expected, the development of critical thinking should not be tied directly to students English ability. Dispositions and skills, if introduced and explained in level-appropriate language, should be as attainable for beginners as they are for advanced students. It is clear that many improvements will need to be made over the lifetime of the CTPB in order to ensure all students develop critical thinking skills and dispositions.

\section{Acknowledgements}

The author would like to acknowledge the following educators, without whom this project booklet would not have been possible. Dr Naoyuki Naganuma for his guidance and feedback on the overall direction of the project and his support for this ambitious addition to the curriculum. Wayne Devitte, primarily for his suggestions and design initiative on the activities and direction of Part 5 of the booklet, and for always being a colleague whom I could bounce my thoughts off of on our morning train rides together. Michael Kelland for his many late nights helping in the design, wording, and overall polish of the booklet. Michael Shraudner, Dr Fergus Hann, Dr Junko Yamaai, and Dr Kahoko Matsumoto for their tireless support in the development of this project and assistance in translating the instructions from English to Japanese.

\section{References}

Atkinson, D. (1997). A critical approach to critical thinking in TESOL. TESOL Quarterly, 31(1). 71-74. doi: 10.2307/3587975

Bell, S. (2010). Project-based learning for the 21st Century: Skills for the future. The Clearing House, 83(7). 39-43. doi:

10.1080/00098650903505415

Bobkina, J., \& Stefanova, S. (2016). Literature and critical literacy pedagogy in the EFL classroom: Towards a model of teaching critical thinking skills.Studies in Second Language Learning and 
Teaching, 6(4), 677-696. https://www.ceeol.com/search/articledetail?id $=471490$

Boholano, H. (2017). Smart social networking: 21st century teaching and learning skills. Research in Pedagogy, 7(1). 21-29. doi: $10.17810 / 2015.45$

Choy, S. C., \& Oo, P. (2012). Reflective thinking and teaching practices:

A precursor for incorporating critical thinking into the classroom? International Journal of Instruction,5(1), 167-182, Retrieved from: https://files.eric.ed.gov/fulltext/ED529110.pdf

Davidson, B. (1998). Comments on Dwight Atkinson's “A critical approach to critical thinking in TESOL": A case for critical thinking in the English language classroom. TESOL Quarterly, 32(1),119-123. doi: $10.2307 / 3587906$

Ellis, R. (2003). Task-based language learning and leaching. Oxford Applied Linguistics.

Kubota, R. (1999). Japanese culture constructed by discourses: Implications for applied linguistics research and ELT. TESOL Quarterly, 33(1), 9-35. doi: 10.2307/3588189

Loschky, L., Bley-Vroman, R. (1993). Grammar and task-based methodology. In G. Crookes, S. Gass. (Eds.), Tasks and language learning: Integrating theory and practice. Multilingual Matters.

Lund, S. (2016). Making learning authentic: an educational case study describing student engagement and motivation in a project-based learning environment. [Doctoral dissertation, Arizona State University]. Arizona State University Library. Retrieved from: https://repository.asu.edu/attachments/170430/content/Lund _asu_0010E_15863.pdf

Murawski, L. (2014). Critical thinking in the classroom... and beyond. Journal of Learning in Higher Education, 10(1). 25-30. Retrieved from: https://files.eric.ed.gov/fulltext/EJ1143316.pdf

Mutakinati, L., \& Anwari, I., \& Kumano, Y. (2018). Analysis of students' critical thinking skill of middle school through STEM education 
project-based learning. Indonesian Journal of Science Education, 7(1),54-65. doi: 10.15294/jpii.v7i1.10495

Nunan, D. (1989). Understanding language classrooms. Prentice-hall International.

Okada, R. (2015). Thinking in the Japanese classroom. Journal of Modern Education Review, 5(1), 1054-1060. doi: 10.15341/jmer(21557993)/11.05.2015/004

Prabhu, N. S. (1987). Second Language Pedagogy. Oxford University Press.

Ruso, N. (2007). The influence of task-based learning on the EFL classroom. Asian EFL Journal, 1-23. Retrieved from: http://www.asian-efl-journal.com/pta_February_2007_tr.pdf Saleh, S. E. (2019). Critical thinking as a $21^{\text {st }}$ century skill: Conceptions, implementations, and challenges in the EFL classroom. European Journal of Foreign Language Teaching, 4(1). 1-16. doi: $10.5281 /$ zenodo. 2542838

Umehara, H. (2015). Developing critical thinking skills in EDC. New Directions in Teaching and Learning English Discussion, 3, 204-210. doi: 10.14992/00015976

Vonglao, P. (2017). Application of fuzzy logic to improve the Likert scale to measure latent Variables. Journal of Social Sciences, 38(3). 337-344. doi: 10.1016/j.kjss.2017.01.002

Willis, J. (1998). Task-based learning: What kind of adventure? The Language Teacher, 22(7). Retrieved from: https://jaltpublications.org/tlt/issues/1998-07_22.7

\section{About the author}

James Dunn is an Associate Professor at Aichi University. His research interests are critical thinking skills and their impact on learning and strategies for the gamification of vocabulary learning through critical thinking. His goal: help students understand they are capable of more than they know through critical thinking skills training. 
